\title{
Immunological study of chronic polyneuropathies of undetermined cause
}

\author{
B. O. OSUNTOKUN, JOHN PRINEAS, AND E. J. FIELD \\ From the Department of Neurology, Royal Victoria Infirmary and University of Newcastle upon Tyne, \\ and the Medical Research Council Demyelinating Diseases Unit, Newcastle upon Tyne
}

The majority of acute idiopathic polyneuropathies causing maximum disability occurring over the course of a few days to a few weeks have the features of the Guillain-Barré syndrome. This is a useful label and has encouraged the study of idiopathic acute polyneuropathies as a whole, providing some evidence of pathogenetic homogeneity within this group whether the neuritis appears de novo or follows a specific virus infection. On the other hand, chronic idiopathic or essential polyneuropathy with a subacute onset and pursuing either a progressive or remitting course, sometimes clearing completely, has attracted very little attention. Diabetic and nutritional neuropathy excepted, the latter constitute the commonest polyneuropathy seen outside the tropics (Perlo and Adams, 1962). The variable clinical course within this group suggests the operation of multiple aetiological factors, and it is perhaps for this reason that the group has not been defined clinically.

Melnick (1963) found complement-fixing antibodies against nervous tissue in six out of 10 patients with chronic polyneuropathy. In his view this supported the holistic concept of acute and chronic idiopathic polyneuropathies, as he also found similar antibodies in $50 \%$ of patients with the Guillain-Barré syndrome. In the same study, however, antibodies against nervous tissue occurred in 30 to $50 \%$ of patients with cirrhosis of the liver, disseminated lupus erythematosus, and also in patients with a variety of hypersensitivity diseases without neurological involvement. This rather slender evidence that immune reactions may play some part in the pathogenesis of chronic idiopathic polyneuropathies is supported by the occasional response to steroid medication seen in some such cases. Furthermore it is probable that circulating antibodies are involved in the pathogenesis of other polyneuropathies-sensory carcinomatous neuropathy (Wilkinson, 1964) and experimental allergic neuritis (Waksman and Adams, 1955) - and their specificity for neural tissue has also been demon- strated using fluorescent antibody techniques (Field, Ridley, and Caspary, 1963; Wilkinson and Zeromski, 1965).

\section{MATERIAL}

Three groups of patients were examined and control blood specimens were obtained from 34 healthy donors attending the Regional Transfusion Centre. Sixteen patients had recovered completely from polyneuropathy; four patients were suffering from polyneuropathy of known cause; 17 had signs of polyneuropathy, of whom 15 could be considered instances of essential or idio pathic chronic polyneuropathy. The latter group hado been extensively and repeatedly investigated. There was no evidence of carcinoma, collagen-vascular disease, diabetes, subacute combined degeneration, or of known nutritional or toxic causes of polyneuropathy in any of the cases investigated. These groups are summarized in Table I.

\section{METHODS}

COMPLEMENT-FIXATION TESTS Saline extracts $(25 \% \mathrm{w} / \mathrm{v})$ of group 0 human brain and sciatic nerve obtained within 12 hours of death were used as antigens and were prepared by the method described by Wilkinson (1964) with $0.03 \%$ sodium azide added as preservative. Small aliquots were stored at $-65^{\circ} \mathrm{C}$. for periods not longer than four weeks before use. Freshly separated sera were inactivated by heating for 30 minutes at $56^{\circ} \mathrm{C}$. and stored in small aliquots at $-65^{\circ} \mathrm{C}$. Complement-fixation tests were carried out and interpreted as described by Caspary, Field, MacLeod, and Smith (1963) with overnight, incubation at $4^{\circ} \mathrm{C}$. and incubation for one hour at $37^{\circ} \mathrm{C}$. Immunofluorescent antibody studies of the doublelayer type were carried out as described by Coons, Leduc, and Connolly (1955) and Nairn (1962) using undiluted serum. Rat and guinea-pig sciatic nerve, spinal cord, and occipital lobe were cut at $4 \mu$ in a cryostat and air-dried or alcohol-fixed sections stained within two hours. Both types of preparation were used for each series of experiments and each serum was tested six times. Sections were treated with serum for the conventional 30 minutes at $37^{\circ} \mathrm{C}$.; for one hour at $37^{\circ} \mathrm{C}$.; and overnight at $4^{\circ} \mathrm{C}$. Staining with fluorescein-conjugated antihuman globulin (Burroughs Wellcome) was limited to 30 minutes at $37^{\circ} \mathrm{C}$. 
TABLE I

PATIENTS EXAMINED IMMUNOLOGICALLY

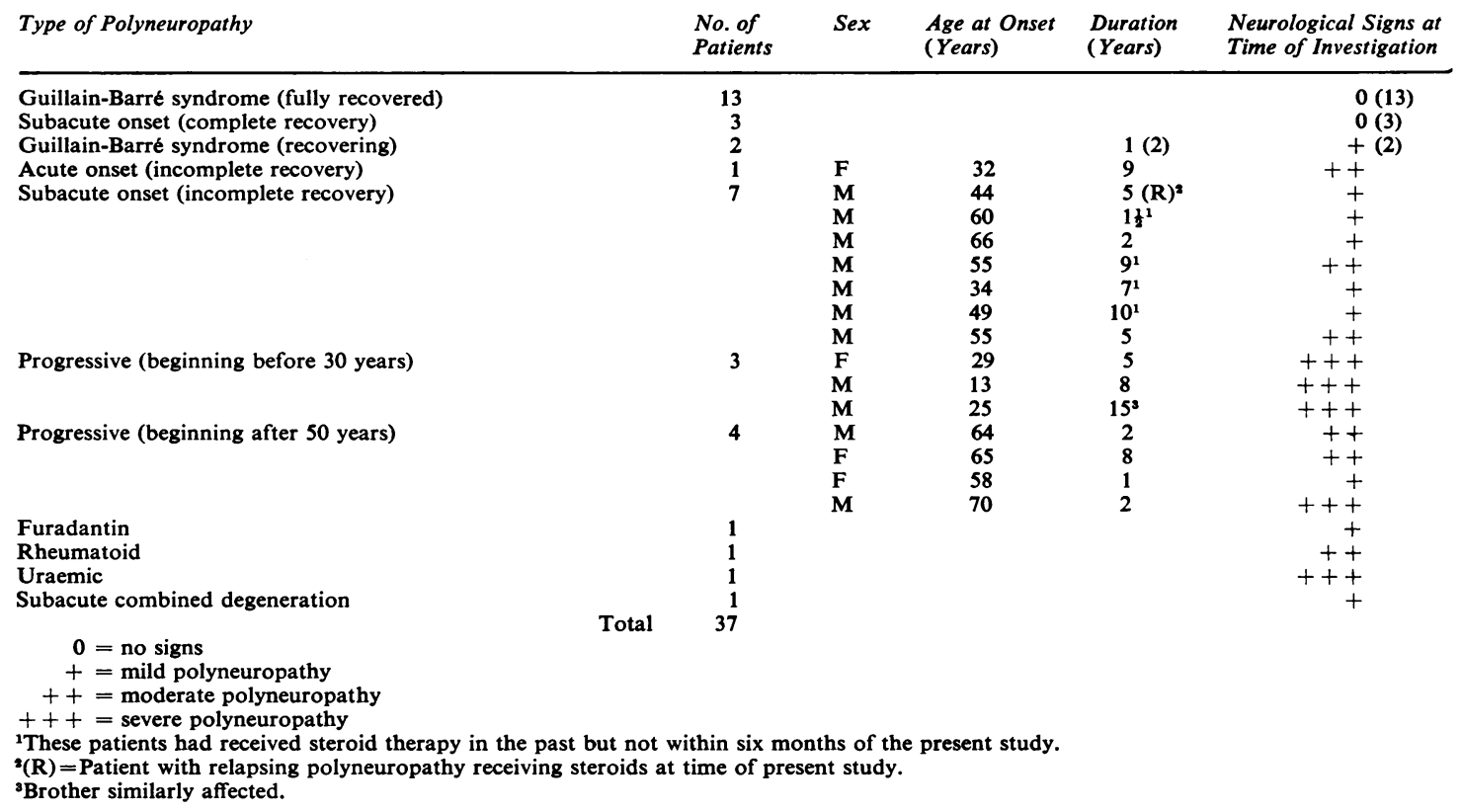

TABLE II

RESULTS OF COMPLEMENT-FIXATION TESTS

$\begin{array}{lllll}\text { Complement-fixation Test } & \text { Positive Negative } & \begin{array}{l}\text { Anti- } \\ \text { complimentary }\end{array} & \begin{array}{l}\text { Total Usable } \\ \text { Untive }\end{array} \quad \text { Negative Anti- } \\ \text { complimentary } & \text { Usable }\end{array}$

Saline extract of human brain as antigen

Overnight incubation of antigen + serum + complement at $4^{\circ} \mathrm{C}$

$1 \mathrm{hr}$. incubation at $37^{\circ} \mathrm{C}$.

7
0

7
0

24

37

6
0

Saline extract of human sciatic nerve as antigen

Overnight incubation of antigen + serum + complement at $4^{\circ} \mathrm{C}$. $1 \mathrm{hr}$. incubation at $37^{\circ} \mathrm{C}$.

$\begin{array}{lll}0 & 31 & 6 \\ 0 & 37 & 0\end{array}$

\section{RESULTS}

The results of the complement-fixation tests are shown in Table II. With prolonged incubation (1620 hours) at $4^{\circ} \mathrm{C}$., using saline extracts of brain as antigen, some positive results were obtained in normal controls as well as in patients. Analysis showed no statistically significant difference between the two groups. No complement-fixing antibodies were found in patients or controls with either brain or sciatic nerve when incubation was carried out at $37^{\circ} \mathrm{C}$. for one hour. Although complement-fixation reactions are claimed to be more complete with prolonged incubation at $4^{\circ} \mathrm{C}$. (Kabat and Mayer, 1961), Roberts (1962) urges caution in the interpretation of 
experiments, the sera from three patients with idiopathic chronic polyneuropathy showed an apparent localization of fluorescein-conjugated antihuman gamma globulin in the axis cylinders of the sciatic nerve sections with none in spinal cord axis cylinders or on peripheral nerve myelin sheaths. However, this reaction could not be consistently repeated and has therefore been set aside as fortuitous. In two other patients and in one normal control fluorescence of the neurones of the occipital lobes was observed, but when compared with the brilliant fluorescence obtained using serum from a patient with antinuclear factor it was felt that these results could not be regarded as significant.

\section{DISCUSSION}

The present study was limited to circulating antibody and does not exclude the possibility of an immune reaction mediated by cell-bound antibody. In this connexion it should be noted that Winkler (1965) has produced demyelination in cultures of foetal rat trigeminal ganglia by the application of lymphocytes from rats with experimentally induced latent allergic neuritis. However, some sera from affected animals also produced demyelination. The present work contrasts with Wilkinson's finding of circulating antibodies in sensory carcinomatous neuropathy but is compatible with his suggestion that they are not merely the result of damaged peripheral nervous tissue. None of the patients in the present series had a predominantly sensory neuropathy of the type seen with carcinoma and the follow-up for six years makes it improbable that any case was carcinomatous in origin.

\section{SUMMARY}

No evidence of an immune pathogenesis in terms of serum antibodies against central and peripheral nervous tissue was found in 15 patients with idiopathic chronic polyneuropathy when complementfixation and immunofluorescent tests were used.

One of us (B.O.O.) held a Smith and Nephew fellowship during the period of this study. We are indebted to Dr. A. Vejjajiva and Miss Greta Joyce A.M.I.L.T. for assistance and to Professor Henry Miller and physicians and general practitioners in the Newcastle Region for access to patients under their care and to Dr. Sheila Murray of the Regional Transfusion Centre.

\section{REFERENCES}

Caspary, E. A., Field, E. J., MacLeod, I., and Smith, C. (1963). Circulating antibody to saline brain extracts in multiple sclerosis. $Z$. Immun.-Forsch., 125, 459-463.

Coons, A. H., Leduc, E. H., and Connolly, J. M. (1955). Studies on antibody production. J. exp. Med., 102, 49-60.

Field, E. J., Ridley, A., and Caspary, E. A. (1963). Specificity of human brain and nerve antibody as shown by immunofluorescence microscopy. Brit. J. exp. Path., 44, 631-634.

Kabat, E. A., and Mayer, M. M. (1961). Experimental Immunochemistry, 2nd ed. Thomas, Springfield, Illinois.

Melnick, S. C. (1963). Thirty-eight cases of the Guillain-Barre syndrome: an immunological study. Brit. med. J., 1, 368-373.

Nairn, R. C. (1962). Fluorescent Protein Tracing. Livingstone, Edinburgh.

Perlo, V., and Adams, R. D. (1962). Diseases of the periphera' nerves. In Principles of Internal Medicine, edited by T. R. Harrison, 4th ed., pp. 1873-1883. McGraw-Hill, New York.

Roberts, S. D. (1962). Circulating antibodies in multiple sclerosis. Lancet, $1,164$.

Waksman, B. H., and Adams, R. D. (1955). Allergic neuritis: an experimental disease of rabbits induced by the injection of peripheral nervous tissue and adjuvants. J. exp. Med., 102, 213-236.

Wilkinson, P. C. (1964). Serological findings in carcinomatous neuromyopathy. Lancet, 1, 1301-1303.

— bodies against neurones in sensory carcinomatous neuropathy. Brain, 88, 529-538.

Winkler, G. F. (1965). In vitro demyelination of peripheral nerve induced with sensitized cells. Ann. N.Y. Acad. Sci., 122, 287296. 